\title{
Analysis of Cropping Pattern Followed by Members and Non-Members of Water Users' Association in Upper Krishna Project Command Area
}

\author{
Veeresh S. Wali $^{1 *}$, R. K. Mishra ${ }^{1}$, B. P. Mohapatra ${ }^{2}$ and S. N. Mishra ${ }^{1}$ \\ ${ }^{1}$ Department of Agricultural Economics, OUAT, Bhubaneswar, India \\ ${ }^{2}$ Department of Extension Education, OUAT, Bhubaneswar, India \\ *Corresponding author
}

\section{A B S T R A C T}

\section{Keywords}

Water users'

association,

Cropping pattern,

Diversification

\section{Article Info}

Accepted:

10 November 2019

Available Online:

10 December 2019
Cropping pattern refers to the proportion of area under different crops at any given point of time in a unit area, or the yearly sequence or spatial arrangement of crops on a given area. An attempt was made to compare the cropping pattern followed by the members and nonmembers of Water Users' Associations in Upper Krishna Project command area. The Upper Krishna Project (UKP) is one of the major projects in Karnataka and is the most prestigious multipurpose (irrigation and power) project. It is the economic lifeline of chronically drought hit districts of North Karnataka. The study made use of both primary data and secondary data. Primary data was collected from the respondents living in the villages of Upper Krishna Project, Karnataka. The data was analyzed using simple tabular analysis which was later compared on the extent of diversification using Herfindahl index. The study concluded that cropping pattern followed by sample farmers in the canal command areas was in favor of water and input intensive crops. However, there is a difference in the per cent area under these crops among the members and non-members of the WUAs. Non-members of WUAs have higher per cent area under water intensive crops like sugarcane as compared to members of WUAs. This difference may be attributed to the awareness about the water conservation, soil health, fertility status and diversification that the farmers have obtained by virtue of being a member of WUA.

\section{Introduction}

Cropping pattern refers to the proportion of area under different crops at any given point of time in a unit area, or the yearly sequence or spatial arrangement of crops on a given area. Cropping activities may run all the year round, provided water is available for crops. It may be of different types such as inter cropping, mixed cropping and crop rotation. The agricultural lands when are occupied by one crop, called as mono cropping, or by two crops, called as double cropping, or more than two crops, termed as multiple cropping. As per availability of water, cropping pattern varies. The prevalent cropping patterns are the cumulative results of past and present decisions by individuals. These decisions are 
usually based on experience, tradition, expected profit, personal performances, Govt. support and so on. The cropping pattern followed by the members and non-members of Water Users' Association in the canal command areas or Krishna river basin is being studied and analyzed through the following research.

The Upper Krishna Project was originally conceived by the erstwhile State of Hyderabad along with the Lower Krishna Project (now known as Nagarjunasagar project). This project could not be initially implemented because the submersion was mostly in Bijapur Dist., which was then not a part of State of Mysore (Karnataka). After the reorganisation of states the scope of the project was modified so as to include two storage reservoirs. In 1973, the Krishna Water Dispute Tribunal (KWDT) adjudicated on the sharing of Krishna river waters between the three riparian states of Maharashtra, Karnataka, and Andhra Pradesh. KWDT - I in its final order dated December 24, 1973 has allocated the $75 \%$ dependable flows of 2060 TMC of Krishna waters amongst three riparian states and the share of Karnataka State aggregated to 734 Thousand Million Cubic Feet (TMC) of water. The further report of the Tribunal dated May 27, 1976 also contained modification of the final order based on references made by different States under Section 5(3) of the Act. The Central government construed the aforesaid final order to be the decision of the Tribunal and accordingly published the same in the Extraordinary Gazette dated May 31, 1976 and on such publication the said final order has statutorily became final and binding on the parties to the dispute. To implement the award, the Government of Karnataka formulated a Master Plan comprising of various projects. One of these projects is the Upper Krishna Project under which it was proposed to utilise $173 \mathrm{TMC}$ of water. In order to derive maximum benefits as early as possible, the project was envisaged to be executed in different Stages and Phases to utilise 119 TMC of water in Stage 1 and 54 TMC in Stage II.

The Upper Krishna Project (UKP) is one of the major projects in Karnataka and is the most prestigious multipurpose (irrigation and power) project. It is the economic lifeline of chronically drought hit districts of North Karnataka, as it would irrigate a command area of $1 \mathrm{~m}$. ha on full development. The irrigation water was first let out in September 1982. The intensity of irrigation originally envisaged in Stage-I was 107.5 per cent.

\section{Materials and Methods}

The study made use of both primary data and secondary data. Primary data was collected from the respondents living in the villages of Upper Krishna Project, Karnataka. The data on the functioning of WUAs, cropping pattern, release of water and area under coverage in distributary was collected and the perceptions of stakeholders in improving the water distribution was documented using the personal interview schedule. Secondary data on cropping pattern, water discharge rates, area, production and productivity was collected from offices of Irrigation departments and Command Area Development Authority, Bheemarayanagudi, Karnataka.

The cropping pattern in study area was analyzed using simple tabular analysis which was later compared on the extent of diversification using Herfindahl index.

\section{Herfindahl index}

It is the sum of square of the proportion of acreage under each crop to the total cropped area and is given by the equation

$$
\mathrm{HI}=\sum^{\mathrm{N}} \mathrm{P}_{\mathrm{i}}^{2} \ldots \ldots \text { (1) }
$$


Where, Pi represents acreage proportion of the $i^{\text {th }}$ crop in total cropped area.

\section{Results and Discussion}

A perusal of table 1 depicts the cropping pattern followed by the members and the nonmembers of WUAs different command areas of UKP. In case of kharif season both members and non-members of WUAs cultivated crops like paddy, maize, pearl millet, pigeon pea, green gram, ground nut and sunflower. About 33.38 per cent area was under cultivation in kharif season with highest area under paddy $(14.35 \%)$ followed by maize $(5.06 \%)$, pigeon pea (4.62), pearl millet $(3.95 \%)$, sunflower $(2.07 \%)$, green gram $(1.83 \%)$ and groundnut $(1.49 \%)$ in case of members. Similarly, in case of non-members, about 34.14 per cent area was under cultivation with highest area under paddy $(15.76 \%)$ followed by sunflower $(5.20 \%)$, maize $(4.95 \%)$, groundnut $(3.08 \%)$, pearl millet $(2.32 \%)$, pigeon pea $(1.62 \%)$ and green gram $(1.21 \%)$.

Similarly, in case of rabi season paddy, sorghum, chickpea and wheat were the important crops grown by members and nonmembers of WUAs. About 27.94 per cent area was under cultivation with highest area under paddy $(13.54 \%)$ followed by chick pea $(5.20 \%)$, sorghum $(4.62 \%)$ and wheat $(4.58 \%)$ in case of members. In case of non-members, about 27.53 per cent area was under cultivation with the highest area under paddy $(15.20 \%)$ followed by chick pea $(5.66 \%)$, sorghum (3.48\%) and wheat (3.18\%).

Further, with regard to bi-seasonal (commercial crops), sugarcane cotton and horticulture crops were predominantly grown by members and non-members of WUAs. About 38.68 per cent area was under cultivation of i=these crops with highest area under sugarcane $(17.63 \%)$ followed by cotton $(16.18 \%)$ and horticulture crops $(4.87 \%)$ and in case of members while in case of nonmembers about 38.33 per cent area was under cultivation with highest area under sugarcane (19.85\%) followed by cotton (14.80\%) and horticulture crops $(3.69 \%)$.

The gross cropped area among the members was 20.76 acres while it was 19.80 acres for non-members. Similarly, the net cropped area was high among the members (14.96 acres) as compared to non-members (14.35 acres).

The cropping intensity among the members $(138.77 \%)$ was high as compared to nonmembers (137.98\%). Further, the Herfindahl indices indicating the diversification of crops was observed to be high among members $(0.15)$ than non- members $(0.17)$.

A close observation of the results presented for the ropping pattern followed by the farmer respondents in the command area was studied and a comparison was made between the farmers who are the members of WUAs and those who are not the members of WUAs.

Nearly one third of the area under cultivation across the canal was for sugarcane. Pigeon pea, pearl millet, green gram, groundnut, sunflower, sorghum, wheat and chick pea were dominant seasonal crops in the command area. The reasons for it may be attributed to agro climatic factors suitable for crops.

Further labour shortage in the area coupled with presence of large number of sugar factories in the region is forcing people to go for crops like sugarcane which involves lesser labour with low drudgery on the farmers along with better competitive market for sugarcane. 
Table.1 Cropping pattern in the UKP region

\begin{tabular}{|c|c|c|c|c|}
\hline \multirow[t]{2}{*}{ Crop } & \multicolumn{2}{|c|}{ Members } & \multicolumn{2}{|c|}{ Non Members } \\
\hline & $\begin{array}{c}\text { Area } \\
\text { (Acres) }\end{array}$ & $\begin{array}{c}\text { Percentage } \\
(\%)\end{array}$ & $\begin{array}{c}\text { Area } \\
\text { (Acres) }\end{array}$ & $\begin{array}{c}\text { Percentage } \\
(\%)\end{array}$ \\
\hline \multicolumn{5}{|c|}{ Kharif } \\
\hline Pigeon pea & 0.96 & 4.62 & 0.32 & 1.62 \\
\hline Groundnut & 0.31 & 1.49 & 0.61 & 3.08 \\
\hline Pearl millet & 0.82 & 3.95 & 0.46 & 2.32 \\
\hline Maize & 1.05 & 5.06 & 0.98 & 4.95 \\
\hline Sunflower & 0.43 & 2.07 & 1.03 & 5.20 \\
\hline Green gram & 0.38 & 1.83 & 0.24 & 1.21 \\
\hline Paddy & 2.98 & 14.35 & 3.12 & 15.76 \\
\hline Sub total & 6.93 & 33.38 & 6.76 & 34.14 \\
\hline \multicolumn{5}{|c|}{$R a b i$} \\
\hline Sorghum & 0.96 & 4.62 & 0.69 & 3.48 \\
\hline Chickpea & 1.08 & 5.20 & 1.12 & 5.66 \\
\hline Wheat & 0.95 & 4.58 & 0.63 & 3.18 \\
\hline Paddy & 2.81 & 13.54 & 3.01 & 15.20 \\
\hline Sub total & 5.8 & 27.94 & 5.45 & 27.53 \\
\hline \multicolumn{5}{|c|}{ Bi-Seasonal/Commercial crops } \\
\hline Sugarcane & 3.66 & 17.63 & 3.93 & 19.85 \\
\hline Cotton & 3.36 & 16.18 & 2.93 & 14.80 \\
\hline Horticulture crops & 1.01 & 4.87 & 0.73 & 3.69 \\
\hline Sub total & 8.03 & 38.68 & 7.59 & 38.33 \\
\hline GCA & 20.76 & 100.00 & 19.80 & 100.00 \\
\hline NCA & \multicolumn{2}{|c|}{14.96} & \multicolumn{2}{|c|}{14.35} \\
\hline CI & \multirow{2}{*}{\multicolumn{2}{|c|}{$\begin{array}{c}138.77 \\
0.15\end{array}$}} & \multicolumn{2}{|c|}{137.98} \\
\hline Herfindahl index & & & \multicolumn{2}{|c|}{0.17} \\
\hline
\end{tabular}

Source: Author's calculation

More than half of the area under cultivation in the region was under paddy followed by a significantly high area under cotton however, pigeon pea, maize, sunflower sorghum, wheat and chick pea were important seasonal crops grown in the region. The possible reasons for the high area under paddy may the congenial agro-climatic conditions for its cultivation couple with competitive markets at national and international levels. Similarly, the presence of international markets for cotton and chilli in nearby areas is prompting the farmers to take up cotton cultivation. Further, the area under pigeon pea is significantly high in the region is the good quality of the crop which is geo-tagged for Kalaburgi region under the registry of Geographical Indication by government of India.

A close observation of results shows the extent of deviation from the recommended cropping pattern by members and nonmembers of WUAs. The extent of deviation among the non-members is higher as compared to members of WUAs. This may be due to the fact that, as members of WUAs, they may have obtained awareness about the judicious use of water. This has led to 
significant deviation in cropping pattern among the members of WUAs.

The study concluded that cropping pattern followed by sample farmers in the canal command areas was in favor of water and input intensive crops. However, there is a difference in the per cent area under these crops among the members and non-members of the WUAs. Non-members of WUAs have higher per cent area under water intensive crops like sugarcane as compared to members of WUAs. This difference may be attributed to the awareness about the water conservation, soil health, fertility status and diversification that the farmers have obtained by virtue of being a member of WUA. This innovative and scientific orientation about cultivation practices in the canal command areas is the result of training and capacity building of the farmers as members of WUAs. Similar findings were reported by Sultanapur (2016) for TBLLC and NRBC canal command area and Wali (2016) in UKP and MGP command areas in Karnataka. The findings obtained are also in line with those obtained by Ganapathy (2009).

\section{References}

Ganapathy KD. 2008. Operationalization of participatory irrigation management in Upper Krishna Project command area - An economic perspective. M. Sc. (Agri.) Thesis, Univ. Agril. Sci., Dharwad

Omondi S, Stephen G, Mbogoh and Kimpei M. 2014. International Journal of Science, Environment and Technology, Vol. 3, No 5, 2014, 1778 $-1789$

Sultanapur. V, 2016, “An economic evaluation of water productivities in upper Krishna project (UKP) and Tungabhadra project (TBP) command areas in Karnataka". M. Sc. (Agri.) Thesis, Univ. Agril. Sci., Raichur.

Wali VS. 2016. Economic Evaluation Of Water Productivity In Upper Krishna Project (UKP) and Malaprabha Ghataprabha Project (MGP) Command Areas, Karnataka. M. Sc. (Agri.) Thesis, Univ. Agril. Sci., Dharwad.

\section{How to cite this article:}

Veeresh S. Wali, R. K. Mishra, B. P. Mohapatra and Mishra, S. N. 2019. Analysis of Cropping Pattern Followed by Members and Non-Members of Water Users' Association in Upper Krishna Project Command Area. Int.J.Curr.Microbiol.App.Sci. 8(12): 1220-1224. doi: https://doi.org/10.20546/ijcmas.2019.812.150 